\title{
A child with an unusual lump in the cheek
}

\author{
V P Sinhabahu ${ }^{1}$, J Hettiarachchi ${ }^{2}$, M Gamage ${ }^{3}$, D H Beneragama ${ }^{4}$
}

Sri Lanka Journal of Child Health, 2018; 47(1): 89-90

DOI: http://dx.doi.org/10.4038/sljch.v47i1.8440

(Key words: Dirofilariasis, lump in cheek, child)

\section{Case report}

A six year old previously healthy girl presented with a painless lump over the right cheek of one month duration. There were no other lumps in the body. She was born to non-consanguineous parents with an uncomplicated perinatal period. Her growth and immunization were age appropriate. Examination revealed an adequately grown child without pallor, bone tenderness or lymphadenopathy. The BCG scar was present. A firm non tender lump measuring $2 \mathrm{~cm} \times 2 \mathrm{~cm}$ was noted in the subcutaneous tissue of the right cheek. There was no hepatosplenomegaly. Cardiovascular, respiratory and nervous system examination was normal.

Ultrasound scan of the cheek revealed an avascular hypoechoic lesion in the deep subcutaneous tissue with surrounding mild inflammatory changes suggestive of a worm granuloma. Erythrocyte sedimentation rate was $14 \mathrm{~mm}$ in the first hour. The haemoglobin was $12.4 \mathrm{~g} / \mathrm{dl}$. The white blood cell count was $8,600 / \mathrm{cu}$ mm with $60 \%$ neutrophils, $35 \%$ lymphocytes. Eosinophil count was $250 / \mathrm{cu} \mathrm{mm}$. Mantoux test was negative.

Excision of the lump through the buccal mucosa was done under general anaesthesia. The lump was found deep to the buccinators muscle and was excised completely. Histology revealed a sheet of eosinophils with granulomatous inflammation

${ }^{1}$ Senior Registrar in Paediatrics, ${ }^{2}$ Registrar in Paediatrics, ${ }^{3}$ Senior Lecturer and Consultant Paediatrician, Professorial Paediatric Unit, Colombo South Teaching Hospital, Kalubowila, Sri Lanka, ${ }^{4}$ Senior Lecturer and Consultant Pathologist, Department of Pathology, Faculty of Medical Sciences, University of Sri Jayewardenepura

*Correspondence: sinbad.lk@gmail.com

(Received on 15 March 2017: Accepted after revision on 17 April 2017)

The authors declare that there are no conflicts of interest

Personal funding was used for the project.

Open Access Article published under the Creative

Commons Attribution CC-BY (CC) (P)

around a mature adult worm morphologically compatible with Dirofilaria repens (Figures 1 and 2 ). The adult worm was excised fully. The child recovered completely.

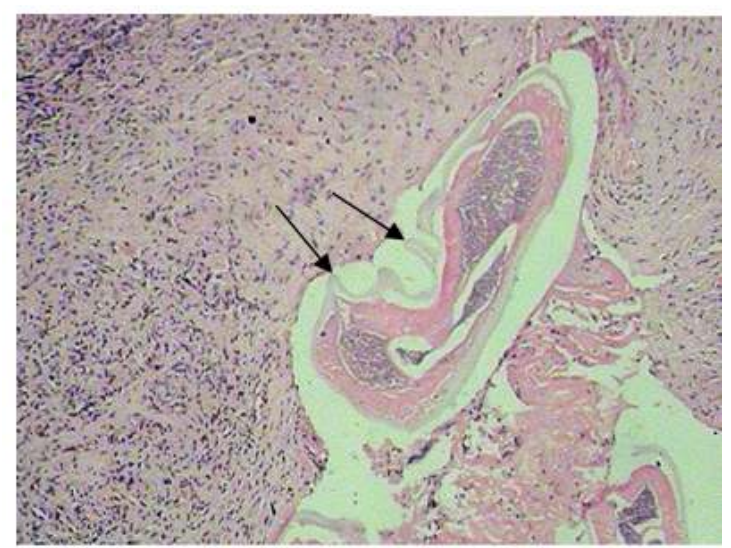

Figure 1: Adult Dirofilaria worm with circular ridges. There is surrounding inflammation. Haematoxylin and eosin $\times 400$

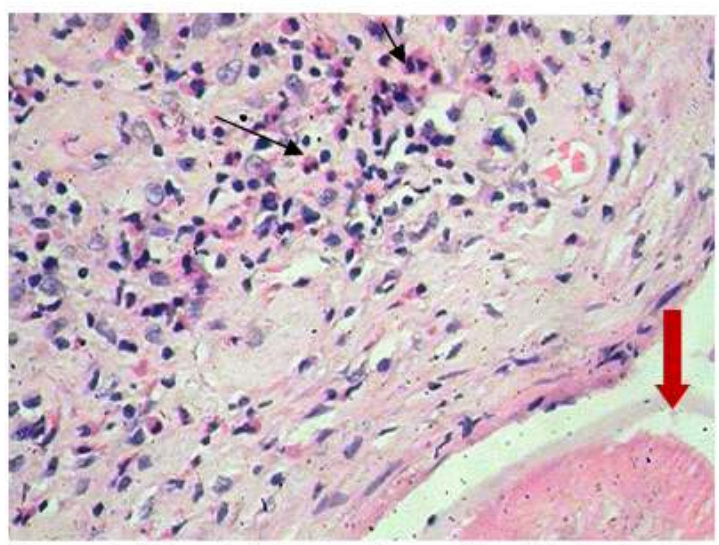

Figure 2: Chronic inflammatory cells with sheets of eosinophils (bilobed nuclei and eosinophilic cytoplasmarrows) adjacent to the adult worm (Block arrow)

\section{Discussion}

Differential diagnosis of a lump in the cheek include fibrosed / calcified lymph node, adenoma arising from the parotid gland or minor salivary glands, an inspissated submucosal abscess, tuberculosis and a foreign body. Parasitic infestation was asymptomatic without eosinophilia.

Dirofilariasis is an uncommon zoonosis where humans are accidental dead end hosts ${ }^{1}$. It is caused by filarial nematodes of genus Dirofilaria, where canines are the principal reservoir host ${ }^{2}$. Subcutaneous nodules, lung parenchymal disease 
and ocular involvement are known manifestations of Dirofilariasis ${ }^{2}$. Aedes aegypti, Armigeres subalbatus, Mansonia uniformis and M. annulifera are mosquito vectors of dirofilariasis ${ }^{3}$. Diethylcarbamazine can be used in the treatment of dirofilariasis ${ }^{4}$. Surgical removal of the subcutaneous nodule is helpful in both diagnosis and treatment ${ }^{2}$. Dirofilariasis should be considered in the differential diagnosis of subcutaneous lumps and ultrasound scan is helpful in the diagnosis.

\section{References}

1. Jayasinghe RD, Gunawardane SR, Sitheeque MAM, Wickramasinghe S. A case report on oral subcutaneous Dirofilariasis. Case Reports in Infectious Diseases 2015; vol. 2015; Article ID 648278

https://doi.org/10.1155/2015/648278

PMid: 26858848 PMCid: PMC4697078
2. Reddy MV. Human dirofilariasis: An emerging zoonosis. Tropical Parasitology 2013; 3:2-3

PMid: 23961434 PMCid: PMC3745666

3. Dissanaike AS, Premaratne UN, Hettiarachchi S, Weerasooriya M, Abeyewickreme W, Ismail MM. Human infection with Dirofilaria (Nochtiella) repens in Sri Lanka. Ceylon Medical Journal 1993; 38(1):.22-4.

4. Senanayake MP, Infaq ML, Adikaram SG, Udagama PV. Ocular and subcutaneous dirofilariasis in a Sri Lankan infant: an environmental hazard caused by dogs and mosquitoes. Paediatrics and International Child Health 2013; 33(2):111-2.

https://doi.org/10.1179/2046905512Y.000 0000024

PMid: 23925286 